Article

\title{
Collective Land Ownership in the 21st Century: Overview of Global Trends
}

\author{
Liz Alden Wily \\ Van Vollenhoven Institute, Leiden Law School, P.O. Box 9520, 2300 RA Leiden, The Netherlands; \\ lizaldenwily@gmail.com; Tel.: +254-724-037-836
}

Received: 30 April 2018; Accepted: 21 May 2018; Published: 29 May 2018

\begin{abstract}
Statutory recognition of rural communities as collective owners of their lands is substantial, expanding, and an increasingly accepted element of property relations. The conventional meaning of property in land itself is changing, allowing for a greater diversity of attributes without impairing legal protection. General identified trends include: (1) declining attempts to deny that community lands are property on the grounds that they may not be sold or are owned collectively; (2) increased provision for communities to be registered owners to the same degree as individual and corporate persons; (3) a rise in number of laws catering specifically to the identification, registration and governance of community property; and (4) in laws that acknowledge that community property may exist whether or not it has been registered, and that registration formalizes rather than creates property in these cases. The research examined the laws of 100 countries to ascertain the status of lands which social communities, either traditionally or in more contemporary arrangements, deem to be their own. Sampling is broadly consistent with numbers of countries per region. The constitutions of all 100 countries were examined. The land laws of 61 countries were scrutinized. Secondary sources were used for 39 countries, mainly due to laws not being available in English. The main secondary source used was LandMark, whose data is publicly available at www.landmarkmap.org.
\end{abstract}

Keywords: property; community lands; customary tenure; collective ownership; statutory law; customary law; alienability

\section{Introduction}

\subsection{The Long Evolution of Property in Land}

As Earle in 2017 analyses, using ethnographic and archeological evidence in the absence of written records, identifiable property goes back 40,000 years [1]. Villages were the dominant landholding units in both the Old and New Worlds. After 10,000 BCE, population growth, intensification of land use, and more settled lives heightened territoriality and needs to defend valuable lands against outsiders. Earle writes

'For property in land, a local group held by cooperative defense the inalienable rights inherited through group membership. As resource use intensified, households that improved land and houses retained some right of personal property, but without the rights to transfer except through inheritance. Land rights were, however, regularly alienated by conquest, whereby a group and its chief asserted direct control by seizure'. (Earle 2017, p. 23)

The comparative utility of collective and individual tenure has been debated in writing since the treatises of Plato and his student, Aristotle, in the 4th century BC [2]. By then, landed property was tied to state-making; property only existing on the say-so of the State, and from which its protection descended. From the outset, state-defined property was individual, male, and private-a relation which 
individuals held with the State, not with each other. Collective or communal tenure was, in contrast, described by Plato as 'natural'; its relations were controlled by, and internal to a self-defining community.

The next two thousand years would refine state-made property as being inseparable from power, wealth, and class formation, and in due course with capitalist transformation, its detachability as a commodity that could be sold sight unseen [3,4]. The umbilical cord of property as a social relation was cut-or so it seemed. How far the greater good of society could be achieved through the accumulation and use of land-based wealth for investment, or through paradigms focusing on equalizing wealth, became one of the great-and continuing-debates of the last four centuries. No philosopher, from Hobbes and Locke onwards, could ignore the role of private property in social change, or battling ideologies around this [5]. Locke's theory of labor in property (1689) was especially influential in distinguishing lands as being either developed or undeveloped (e.g., cultivated or not). This was unhelpful to societies that purposely harvested from, rather than transformed, their lands. This legacy which continues to discriminate against off-farm communal ownership over forests, rangelands and marshlands, key resources for millions of land dependents.

By the 20th century, mitigation against rampant involuntary losses of unrecorded property focused either on welfarism to support the landless, homeless, unemployed, and amassing urban poor in industrialized nations, or upon redistribution of productive farmlands in 50+ agrarian economies [6]. Post-war liberation of colonial polities generally failed to liberate these from European definitions of property; many new administrations promptly vested their entire land area in the state in the name of nationalism. Communities with unfarmed lands were most affected, these widely declared as public properties controlled by governments [7]. Whether ideology was communist, socialist, nationalist, or capitalist, a dominant shared strategy in the 20th century was that community-based tenure (or customary tenure as usually known) must be extinguished in the interests of progress, along with feudal or neo-feudal tenure where this existed (especially in Asia and Latin America). Extinction of community tenure was advanced either through individualization and market-led concentration of ownership, or by the mass reconstruction of rural land use in state-run collectives on national lands [8].

\subsection{The Survival of Community-Based Tenure}

In this context, it may seem extraordinary that community-based property relations still vibrantly existed as the 20th century drew to an end. Or that community claims to shared off-farm lands within their traditional domains, had hardened, rather than dissipated. Reasons included: local reaction to decreasing land availability and rising threats of official takings; the reality that coerced conversion of customary rights into individualized statutory forms was never as widespread or successful as intended; and that, despite massive social transformation, traditional community-based tenure retained an embedded logic as practical, cost-free, and adaptive through iterative consensus. The values of shared off-farm lands also came to the fore, and collective claims more defined. This was in relation to rights within the community as class formation advanced, in relation to defining 'our land' in relation to neighbouring communities, and in relation to the claims of government agencies. Frustration with state land policy, and the statutory failure to protect untitled but locally 'owned' lands grew $[9,10]$.

\subsection{Bringing Collective Landholding in from the Cold}

The last three or four decades launched widespread reformism. This has been less focused on redistribution than on forms of admissible ownership. Political upheavals have regularly been a trigger. By 1989 redistributive farmland reforms in Asia and Latin America had largely ground to a halt. The Soviet Union and its dominance of Eastern Europe ended officially on Christmas Day, 1989 , with the demise of state collectives and in some countries, saw the conversion of local smaller collectives into self-governing community domains, comprising both private farms and attached communal pastures and forests. China had gone through a reform of its own regime of collectivization, with a new household responsibility system in 1984, permitting the privatization of farmlands, and new rules concerning off-farm lands within the collective [11]. 
The communist/socialist world was not the only one to be affected; the 1990s also saw a rash of transformations of one-party states into multi-party democracies in Africa, Asia, and Latin America. These regularly included constitutional commitments to devolved governance, impacting upon land governance. Forceful structural adjustments by global lenders also provided a trigger; while these demanded accelerated individualization and a free land market, national reviews prompted rethinking as to the viability of individualization in all circumstances, to which lending agencies would themselves begin to concede $[12,13]$.

Meanwhile, Indigenous Peoples, a comparatively small sector of traditional community landowners, were making progress in claiming territorial lands in Latin America, Canada, Australia and New Zealand [14,15]. They were rewarded in 1989 with a United Nations Convention, which stated that "the rights of ownership and possession of the peoples concerned over lands which they traditionally occupy shall be recognized", that "Governments shall take steps as necessary to identify these lands" and "guarantee effective protection ... " (ILO 169, Article 14) [16]. Peasant and former slave communities also organized, notably in the creation of La Via Campesina in Brazil in 1993. This expanded globally and along with other new people-led organizations share demand for recognition of the right to own and control occupied and used lands including those that are uncultivated or cleared [17,18]. A draft Declaration on the Rights of Peasants and Other People Working in Rural Areas is to be debated by the United Nations later this year, including sections on property rights [19].

Legal land reform since the 1980s has been expansive. By 2000, more than 50 countries had both new national constitutions in place pledging tenure reforms, and new laws delivering the details. Not all were as transformational as originally intended. Yet most opened the door to new recognition of untitled rural lands. Some radically transformed 20th century prescriptions of how property in land is defined and protected.

\section{Objectives and Methods}

\subsection{Objectives}

The goal of this study is to examine this development as it exists today, and the form which reforms take in respect to community landholding, whether this has been customary and of long-standing, or more contemporarily constructed. Specific objectives are to answer these questions:

1. What are the global extent, strength, and trends in legal provisions for community property?

2. What are the contexts through which recognition of community lands as property are provided?

3. How equally does the law protect community and private property?

4. How is title to community property vested?

5. How far is community property able to be freely sold?

6. How far do laws enable community members to hold private rights to parcels within community properties?

7. To what extent do community owners govern their own properties?

\subsection{Materials and Methods}

All 195 sovereign states of today govern themselves and their lands through statutory laws including, as relevant, how customary land law is positioned. The focus is therefore on the content of state laws. Table 1 lists the 100 countries where these are surveyed. This is a sufficient number to compensate for the absence of entirely random sampling. The selection of countries was determined in large part by the author's familiarity with the laws, or ease of access to reliable information for other countries. Table 2 shows that the sample roughly coincides with the numbers of countries in each continental zone. For a number of subjects addressed in this research, smaller samples are used, thereby excluding countries where the information on the subject was insufficient. 
Laws examined include national constitutions and land laws. The latter often include laws dedicated to the subject of community landholding (e.g., Kenya's Community Land Act, 2016, Nicaragua's Law of Communal Property Regime of Indigenous and Ethnic Communities, 2003, Kyrgyzstan's Law on Pastures, 2009, and Norway's Law On Bygd Commons, 1992).

Table 1. The Sample: Countries Assessed for National Law Provision for Community Property.

\begin{tabular}{llc}
\hline \multicolumn{1}{c}{ Region } & \multicolumn{1}{c}{ Countries in Sample } & No. \\
\hline $\begin{array}{l}\text { AFRICA } \\
\text { Sub Saharan Africa }\end{array}$ & $\begin{array}{l}\text { Angola, Botswana, Burkina Faso, Ivory Coast, Eritrea, Ethiopia, Ghana, Kenya, } \\
\text { Malawi, Republic of Congo, Cameroon, Central African Republic, Chad, Liberia, } \\
\text { Lesotho, Gabon, Mali, Mozambique, Namibia, Rwanda, Sierra Leone, } \\
\text { South Africa, South Sudan, Swaziland, Tanzania, Uganda, Zambia, Zimbabwe }\end{array}$ & 28 \\
\hline North Africa & Algeria, Mauritania, Morocco, Tunisia & 4 \\
\hline MIDDLE EAST & Iraq, Israel, Jordan, Syria & 4 \\
\hline EUROPE \& USSR & $\begin{array}{l}\text { Austria, Bulgaria, Germany, Italy, Norway, Czech Republic, Hungary, Iceland, } \\
\text { Ireland, Latvia, Russia, Sweden, Turkey, Portugal, Romania, Spain, Ukraine }\end{array}$ & 17 \\
\hline ASIA: West and Central & Afghanistan, Armenia, Kyrgyzstan, Turkmenistan, Tajikistan & 5 \\
\hline East, South, and South & $\begin{array}{l}\text { Cambodia, China, Timor Leste, Indonesia, Laos, India, Philippines, Malaysia, } \\
\text { East Asia }\end{array}$ & Bangladesh, Myanmar, Mongolia, Nepal, Pakistan, Sri Lanka, Thailand, Vietnam \\
\hline OCEANIA & Fiji, Australia, New Zealand, Papua New Guinea, Vanuatu & 16 \\
\hline AMERICA & Canada, USA & 5 \\
\hline North America & Cuba, Mexico, Nicaragua, Costa Rica, Panama, Jamaica, Dominica & 2 \\
\hline Central America & $\begin{array}{l}\text { Bolivia, Ecuador, Brazil, Chile, Colombia, Peru, Argentina, Guyana, Paraguay, } \\
\text { South America }\end{array}$ & 12 \\
\hline
\end{tabular}

Note: bold denotes countries where the author has directly examined the laws.

Table 2. Percentage of States by Region and in the Research Sample.

\begin{tabular}{ccccc}
\hline Mesa-Region & $\begin{array}{c}\text { Number of } \\
\text { Countries in Region }\end{array}$ & $\begin{array}{c}\text { Percent in } \\
\text { World }\end{array}$ & $\begin{array}{c}\text { Number of Countries } \\
\text { in Sample by Region }\end{array}$ & $\begin{array}{c}\text { Percent in } \\
\text { Sample }\end{array}$ \\
\hline Africa & 54 & 27.7 & 32 & 32 \\
Asia & 48 & 24.6 & 25 & 25 \\
Europe & 44 & 22.5 & 17 & 17 \\
Latin America \& Caribbean & 33 & 17.0 & 19 & 19 \\
Oceania & 14 & 7.2 & 5 & 5 \\
North America & 2 & 1.0 & 2 & 100.0 \\
\hline
\end{tabular}

Data derives from the author's research for 61 countries, highlighted in bold in Table 1. Data for the remaining 39 countries derives from legal reviews at LandMark (www.landmarkmap.org). LandMark is an interactive global site providing information on the lands of indigenous and other communities, to which the author contributes. While legal critique at LandMark is sometimes incomplete, its conclusions are considered sufficient for the broadly comparative purposes intended here. The use of LandMark and other secondary information was necessary in 36 of the 39 cases due to unavailability of texts in English. Relevant laws in Canada, Australia, and USA were only partially examined due to their immense number. Deciding whether a country's laws were deservedly assessed as positive or negative was not easy in especially six cases, fortunately falling equally in where they were ultimately located.

\subsection{Community Lands: A Massive Estate}

Readers are reminded that this critique focuses on what the law says, not what exists in practice.

It should also be noted that reference to community lands covers lands belonging to both Indigenous Peoples and to other rural communities, and is also without distinction as to how far these are defined on the basis of custom. Globally, community landholders include an estimated 2.5 to 
3 billion rural dwellers, and their combined community land estate is estimated as more than 6 billion hectares, although much of this is not yet acknowledged as their property [20]. Figure 1 illustrates high proportions of community lands where country data is available. Figure 2, with information also available for only some countries, illustrates where community lands are mapped and are legally acknowledged as existing, thus far with or without registration and issue of title.

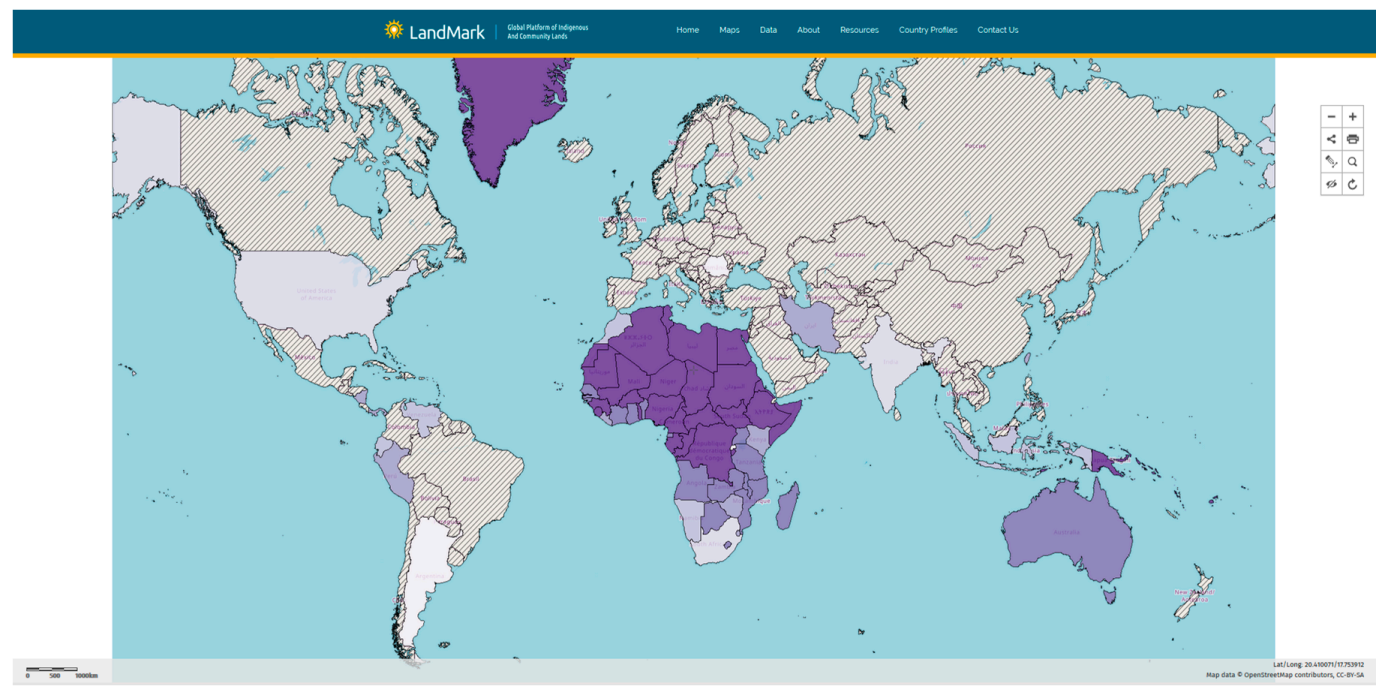

Figure 1. Slowly Discovering a Massive Community Land Resource (as of 2015). Note: The darker the shade, the higher the percentage of country area that is the land of communities (including Indigenous Peoples). The darkest shade is where these lands are estimated to constitute 80 percent or more of the country area. Community/Indigenous Peoples lands may, or may not be, recognized as owned in national laws [21]. Source: Screenshot from the publicly- available site on community and Indigenous Peoples land: www.landmarkmap.org.

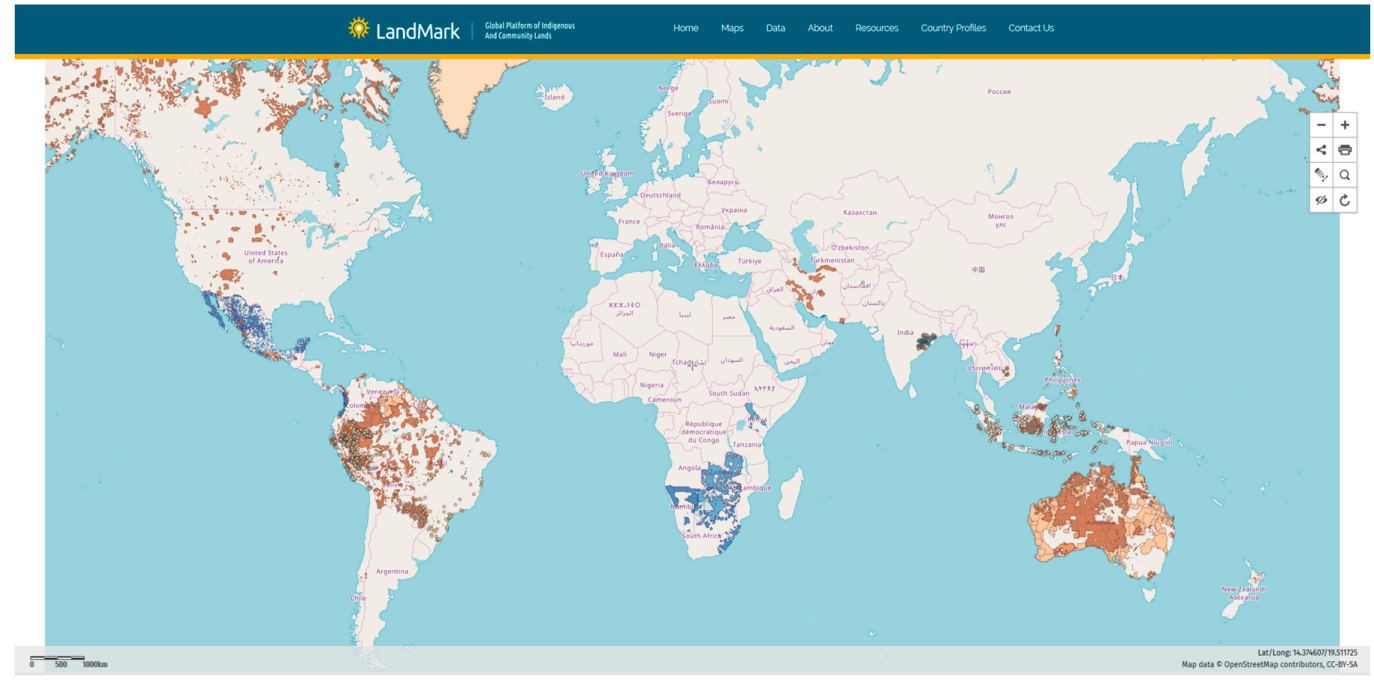

Figure 2. Partial Progress in Mapping and Recognizing Community and Indigenous Peoples Lands (2017). Note: Brown refers to Indigenous Peoples lands. Blue refers to lands of other communities. Dark brown and dark blue means these lands are registered or otherwise legally acknowledged. Light brown and light blue mean these mapped lands are not yet formalized, on a case-by-case basis. Blank means no data; millions of hectares of unidentified community lands exist in many countries, and where no mapping has yet been conducted. Source: Screenshot from the publicly-available site on community and Indigenous Peoples land: www.landmarkmap.org. 


\section{Results-Trends}

\subsection{Legal Recognition of Community Property is Substantial}

Most jurisdictions provide for land to be held individually or in association as others. The latter has been conventionally interpreted as ownership by corporations, cooperatives, and associations, or as co-owners of listed assets, such as lifts and basements in condominium law. Legal provision for social entities to be legal owners, such as the family, clan, village or community, is historically uncommon. It is therefore noteworthy to find that 73 percent of countries in this sample do provide for collective tenure by communities (Table 3).

Table 3. Countries where laws provide for community property presented by region.

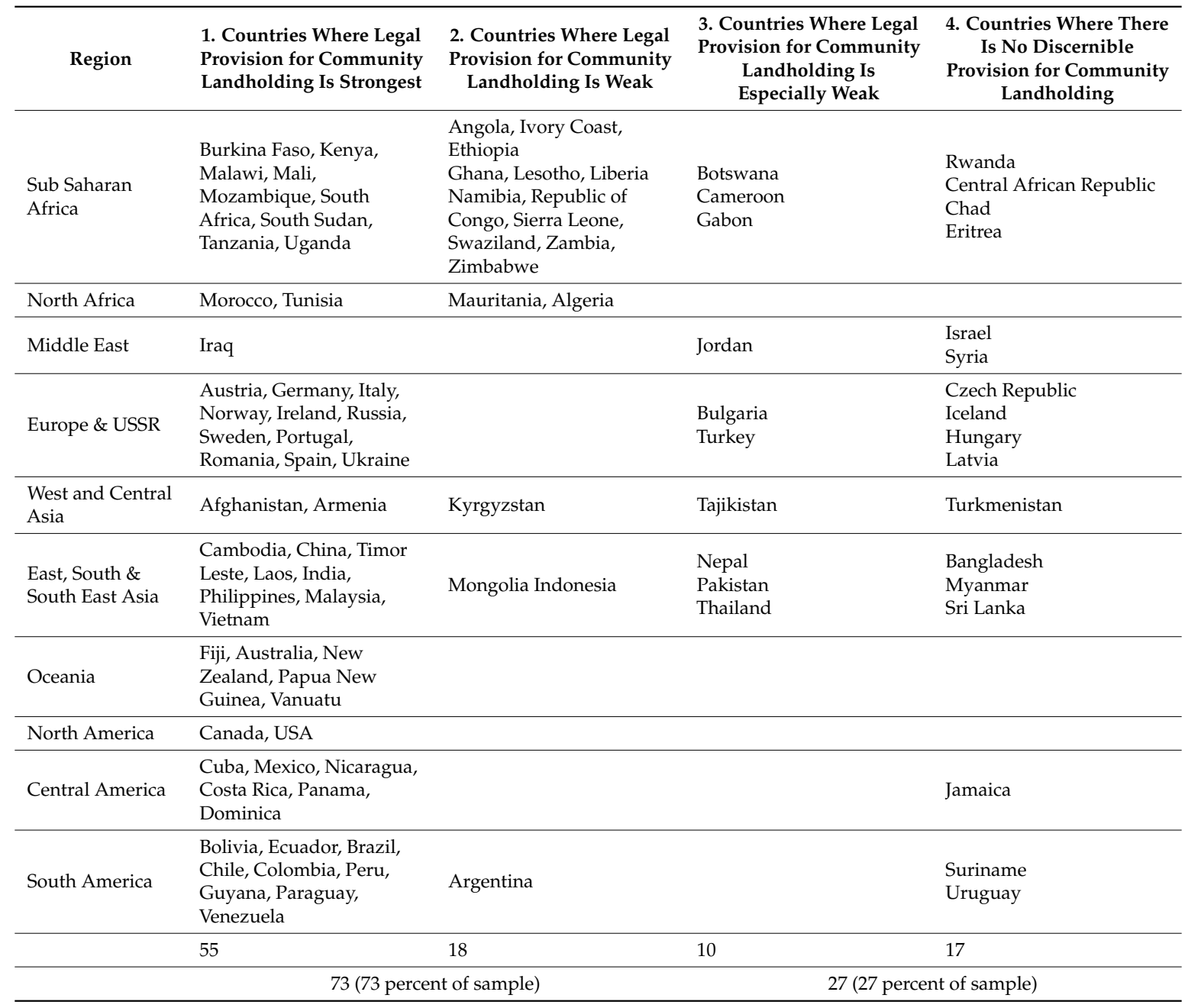

\subsection{Improved Recognition of Community Property is not Confined to a Few Regions}

Table 3 also illustrates the extent of legal acknowledgement of community property by region. Some regions deserve note. All reviewed countries in North America and Oceania provide for community-based ownership. These include many Pacific Island states, where recognition of customary land ownership has existed for some decades. Legal change in Latin America and Africa is also positive; respectively, 84 percent and 78 percent of sampled countries in these regions acknowledge community lands as being lawfully owned.

Latin America is also a part of the world where farmland redistribution dismantling large estates was advanced in 14 states during the 20th century [22]. This contributed significantly to present-day provisions for communities to be lawful landowners, whether as farming collectives (Chile, Peru, 
El Salvador, Nicaragua, Mexico), land associations (Honduras), peasant lands (Bolivia, Peru), or state cooperatives (Cuba). Political reforms also resulted in Indigenous Peoples acknowledged as collective landowners of traditional territories, embedded in new Constitutions in Panama (1972), Peru (1979), Chile (1979), Guatemala (1985), Nicaragua (1987), Brazil (1988), Colombia (1991), Paraguay (1992) Argentina (1994), Bolivia (1995), Ecuador (1998), Venezuela (1999), and Mexico (2001). Despite different phases of reformism over the last century, including de-collectivization and privatization, collective landholding and jurisdiction remains an active component of the property system in Latin America. In Mexico, for example, collective lands exist in 29,000 ejidos (farming communities) and 2160 comunidades (domains of Indigenous Peoples) [23]. Together, these cover nearly half of Mexico. Around 7000 out of 10,000 comunidad nativa and comundidad campesina in Peru hold formal collective titles to their lands [24].

State law recognition of community lands in Africa is also notable. This is partly due to the limited reach of compulsory conversion programs, extinguishing customary rights in favor of individual, state-issued titles, thereafter administered by Governments, not communities. Such 'private property' dominates in only six of 54 states, and covers only 10 percent of Africa [25]. Customary tenure is estimated to prevail over 78 percent of the continent. Political will to forcefully individualize community lands declined from the late 1980s, not least because many beneficiaries failed to collect their certificates, or to record transfers (2), women and family members resented the absence of their names on such documents, and (3) promised opportunities for bank loans on the basis of title deeds failed to be available for small farmers [26-28]. Where individualization was especially active, such as in Kenya, titling eventually reached arid areas, where individualization was rejected as irrelevant by pastoral and agro-pastoral communities, more interested in securing their communal pasturelands [29].

Political reforms swept Africa a decade later than in Latin America, but with comparable incentives to adopt new approaches to property, among other changes. Some new national constitutions in the 1990s led the way in acknowledging customary tenure as producing lawful interests, and as a lawful system for regulating these rights; Constitutions of Namibia (1990), Mozambique (1994), Uganda (1995), South Africa (1996), and the new land laws of Tanzania in 1999.

Twenty years later, in 2018, 31 of 54 African states (57.4 percent) have enacted new land laws. Twenty-one of these are in this sample. Only three fail to improve community land security: two by abolishing customary tenure (Eritrea, Mauritania), and one by co-opting traditionally communal valley and forested lands as state property (Rwanda). Mauritania has since found it necessary to assure pastoralists' collective rights to traditional grazing lands, and is accordingly included in the list of (weakly) positive providers of lawful collective landholding.

\subsection{Laws in Over Half of Sample Countries Provide Strongly for Community Property}

Columns 1 to 4 in Table 3 above cluster variations in the strength of legal support for community property. Laws of countries listed in column 1 share these attributes:

1. Acknowledgement that community-based, collective landholding produces lawful property interests, including those owned collectively;

2. Community and private lands have different attributes, but enjoy equivalent levels of protection;

3. Recognition and protection is not restricted to farms and houses; rangelands, marshes, and forests within the community domain are also acknowledged as community property;

4. Community regulation of community lands is accepted and/or instituted, with greater formality in law;

5. Mechanisms for registration of community properties are legally provided for; and

6. Individual and family interests to specific parts of the community property are acknowledged and nested under collective tenure as derivative rights. 


\subsection{Shortfalls in Legal Provision Are Similar Across Countries}

It is useful to identify common shortfalls in providing for community property. Table 4 gives reasons why countries listed in column 2 of Table 3 as "providing for community property" do so weakly. Three limitations dominate:

1. collective landholding is not given the same legal support as that of individual rights, even where customary rights are acknowledged as property interests (e.g., Ethiopia, Sierra Leone);

2. communities are unable to register collective properties (e.g., Ghana, Indonesia); and

3. main laws have failed to be followed up with essential regulations or decrees enabling application (e.g., Argentina, Republic of Congo).

It will be observed that many countries listed in Table 4 have proposed changes in the handling of community/customary tenure in hand in the form of draft policies or laws.

Table 4. Weaknesses in Legal Provision for Community Property.

\begin{tabular}{|c|c|c|}
\hline Country & Law Referred To & Main Weaknesses in Providing for Community Property \\
\hline Angola & Land Law, 2004 & $\begin{array}{l}\text { Certificates of Useful Domain may be granted to communities but do not have } \\
\text { the same standing as provided to certificated private rights. In addition, } \\
\text { community domains may not include forested lands. }\end{array}$ \\
\hline Ivory Coast & Rural Land Law, 1998 & $\begin{array}{l}\text { While provisions are made for collective ownership by communities, this is } \\
\text { obtainable only through extinction of customary rights and vesting of the shared } \\
\text { land in a legal entity, a costly process, with almost zero uptake thus far. }\end{array}$ \\
\hline Algeria & Law on Land Tenure, 1990 & $\begin{array}{l}\text { The law coerces sedentization by requiring agro-pastoral communities to develop } \\
\text { lands for cultivation in order to secure tenure. }\end{array}$ \\
\hline Kyrgyzstan & Law on Pastures, 2009 & $\begin{array}{l}\text { Although communities are fully assisted to establish Pasture Unions to which } \\
\text { pastures are allocated, these firmly remain the property of the State. }\end{array}$ \\
\hline Mongolia & $\begin{array}{l}\text { Law on Allocation of Land to } \\
\text { Mongolians for Ownership, } 2002\end{array}$ & $\begin{array}{l}\text { As above. Plans to issue longer-term rights to pastoralists are intended in a draft } \\
\text { Pasture Code, } 2017 .\end{array}$ \\
\hline Indonesia & $\begin{array}{l}\text { Regulation No. } 5 \text { of } 1999 \text { under } \\
\text { Basic Agrarian Law, } 1960\end{array}$ & $\begin{array}{l}\text { Collective tenure (hak ulayat) is legally acknowledged as existing but without } \\
\text { a construct yet developed after nearly } 60 \text { years through which this may be } \\
\text { registered. This is reputedly being developed in } 2018 .\end{array}$ \\
\hline Argentina & Constitution, 1994 & $\begin{array}{l}\text { While the law commits the State to register indigenous community lands } \\
\text { pursuant to the Constitution 1994, and ILO } 169 \text { has been adopted in principle, } \\
\text { no law yet exists laying out procedures for this registration. }\end{array}$ \\
\hline Ethiopia & $\begin{array}{l}\text { Federal Land Use Proclamation, } \\
2005\end{array}$ & $\begin{array}{l}\text { Provision for communal landholding is an afterthought in the law, and not } \\
\text { as easily registrable as for homesteads. Oromia Regional State is exploring } \\
\text { ways to achieve this for the vast rangelands of pastoral communities, } \\
\text { with promising progress. }\end{array}$ \\
\hline Ghana & $\begin{array}{l}\text { Constitution, 1992, Title } \\
\text { Registration Act, } 1986\end{array}$ & $\begin{array}{l}\text { Collective property as vested in tribal heads and heads of families is } \\
\text { constitutionally protected, but land laws are yet to provide for the registration of } \\
\text { customary property that is neither allodial title held by chiefs as trustees, nor } \\
\text { individual customary freehold allocated to individuals. The Land Bill, } 2016 \\
\text { provides for collective title, but yet to be finalized and enacted. }\end{array}$ \\
\hline Lesotho & Land Act, 2010 & $\begin{array}{l}\text { While rangelands are held collectively under customary tenure and administered } \\
\text { by elected village councils, arrangements for this are missing in the law. }\end{array}$ \\
\hline Liberia & Public Lands Law, 1973 & $\begin{array}{l}\text { While the Community Forest Rights Act, } 2009 \text { recognizes community forest } \\
\text { property, the Land Rights Bill, } 2016 \text { providing for community based tenure in } \\
\text { general is yet to be enacted. A number of Aboriginal Title Deeds from the 1940s } \\
\text { and 1950s exist covering large areas but often overlaid by State forest reserves. }\end{array}$ \\
\hline Namibia & Communal Land Reform Act, 2002 & $\begin{array}{l}\text { Changes were made to the law in } 2014 \text { to enable families and groups to hold } \\
\text { homestead lands in common, but not extended to grazing commonage, the maor } \\
\text { asset; grazing lands are retained by paramount chiefs as theirs to allocate and } \\
\text { administer. In addition, ownership of Communal Lands in general remained } \\
\text { vested in the State, not the case for freeholds or leaseholds. }\end{array}$ \\
\hline Sierra Leone & Provinces Land Act, 1927 & $\begin{array}{l}\text { The law permits the State to reallocate customary lands that are not farmed for } \\
\text { private or state purposes.. The new National Land Policy, } 2015 \text { proposes reforms } \\
\text { that make all customary rights registrable in the same manner as private rights, } \\
\text { including family and collective tenure, modernize the role of traditional } \\
\text { authorities thorugh inclusive governance measures. }\end{array}$ \\
\hline
\end{tabular}


Table 4. Cont.

\begin{tabular}{|c|c|c|}
\hline Country & Law Referred To & Main Weaknesses in Providing for Community Property \\
\hline Swaziland & Constitution, 2005 & $\begin{array}{l}\text { The King owns Swazi National Lands }(<50 \% \text { of country area) on behalf of the } \\
\text { nation and administers these through a hierarchy of chiefs extending to village } \\
\text { level. No legal procedure exists for communities to identify their domains or } \\
\text { protect against Government or King-led additions to the private property sector } \\
\text { comprising freehold parcels. }\end{array}$ \\
\hline Zambia & $\begin{array}{l}\text { Land Act, } 1995 \\
\text { Lands (Customary Tenure) } \\
\text { (Conversion) Regulations, } 2006\end{array}$ & $\begin{array}{l}\text { While the law admits customary tenure as regulating landholding (now } \\
\text { estimated as } 60 \% \text { of country), it makes no provision for customary rights to be } \\
\text { registered, either as owned individually or collectively. The draft national land } \\
\text { policy (2017) provides for this and also for distinct governance of common lands, } \\
\text { and limitation on powers of traditional authorities to dispose of lands without } \\
\text { community consent. }\end{array}$ \\
\hline Zimbabwe & Communal Land Act, 1982 & $\begin{array}{l}\text { Communal Lands are customarily occupied lands and homesteads may be } \\
\text { certificated, not the case for community commons although their communal } \\
\text { ownership is accepted in principle. A new land policy is in draft. Rural Councils } \\
\text { are primary decision-makers although local headmen execute rules. }\end{array}$ \\
\hline $\begin{array}{l}\text { Republic of } \\
\text { Congo }\end{array}$ & $\begin{array}{l}\text { Principles of General Application } \\
\text { to National Lands and Tenure, } \\
\text { 2004. Rights of Indigenous } \\
\text { Peoples, } 2011\end{array}$ & $\begin{array}{l}\text { Relevant laws for rural communities and Indigenous Peoples lack } \\
\text { implementation decrees after many years. }\end{array}$ \\
\hline
\end{tabular}

Countries with Limited or No Provision for Community Property

Table 3 also lists the 27 countries in the sample where lawfully protected community landholding is especially weak, or for which no such provision for is found. Borderline cases are illustrated below.

Article 67 of the 2007 Constitution of Thailand establishes that communities have the right to participate in the management, maintenance, and exploitation of natural resources, but without provision for ownership. Indigenous communities have only the right to use state-owned lands for livelihood under the Regulation of the Prime Minister's Office on the Issuance of Community Title Deeds, 2010.

The Constitution of Pakistan recognizes customary law in the Federally Administered Tribal Areas in the west of the country. The Land Reform Act, 1977 did not entrench collective rights or governance by village and higher tribal councils.

In Botswana, Tribal Land is the main class of landholding by area and number of persons affected and acknowledged by the Tribal Land Act, 1968. However, rights to allocate lands have since been centralized into largely unelected boards reporting to the national government. Opportunities for villages to formalize their traditional rights to specific rangelands have also been undermined by legal provision for individuals to access these lands under common law leases. Legal provision does not exist for either Indigenous Peoples (San hunter-gatherers) or settled agro-pastoral communities to obtain collective certificates over shared lands, without forming commercial ranching syndicates.

In Turkey, communities may access grazing lands on a collective basis under the Law on Pastures, 1998, although allocation is vulnerable to changes. This is also the case in Tajikistan (amendments in 2008 may have altered this, not accessible in English).

In Nepal, the elderly Land Act of 1964 does not recognize collective landholding. This is despite failed protection of land rights being one of the grievances inducing a decade-long civil war, and the reality that 18,000 forest user groups have rehabilitated local forests since the 1980s, and are seeking secure tenure over those forests. Anticipated provision for collective property did not appear in the new Constitution of 2015, but is briefly referred to with respect to Indigenous Peoples but not to all communities in a draft National Land Policy (2018).

\subsection{There Is an Upward Trend in Legal Recognition of Community Property}

An upward trend is implied (but not proven) in the dates of relevant enactments thus far. Table 5 lists the main law considered in the 73 countries where protection for community-based land rights is provided for. Fifty-seven of these 73 laws were enacted after 1980 (78 percent). 
Table 5. Principal law recognizing community property in 73 states.

\begin{tabular}{|c|c|}
\hline Country & Law and Date of Enactment \\
\hline Afghanistan & Land Management Law, 2017 \\
\hline Algeria & Law No. $90-25$ of 1990 Concerning Land Tenure \\
\hline Angola & Land Law, 2004 \\
\hline Armenia & Land Code, 2001 \\
\hline Argentina & Constitution, 1994 \\
\hline Australia & Native Title Act, 1993 \\
\hline Austria & Entire Legislation for Constitution Act, 1951 \\
\hline Bolivia & Law 3545 of November 2006 on New Land Reform \\
\hline Brazil & Constitution, 1988 with amendments. Land Statute, 1964 \\
\hline Burkina Faso & Law No. 034-2009 On Rural Land Tenure \\
\hline Cambodia & Land Law, 2001 \\
\hline Canada & Constitution Act, 1982 \\
\hline Chile & Law on Agricultural Communities, No. 5 of 1968. Indigenous Law, No. 19/1979 \\
\hline China & Property Law, 2007 \\
\hline Colombia & Rural Land Law, 1998 \\
\hline Costa Rica & Indigenous Law, No. 6172 of 1977 \\
\hline Ivory Coast & Rural Land Law, 1998 \\
\hline Cuba & Agrarian Reform Law, 1959 \\
\hline Dominica & The Carib Reserve Act, No. 22 of 1978 \\
\hline Ecuador & Law No. 46-2006 the Collective Rights Act of Afroecuadoreans \\
\hline Ethiopia & Federal Land Use Proclamation No. 456 of 2005 \\
\hline Fiji & iTaukei Land Trust Act, 1940 \\
\hline Ghana & Constitution 1992. The Office of The Administrator of Stool Land Act, 1994 \\
\hline Germany & German Constitution (Basic Law) 1951. Federal Forest Act 1975 \\
\hline Guyana & State Lands Act, 1910 (1997) \\
\hline Indonesia & $\begin{array}{l}\text { Basic Agrarian Law, No. } 5 \text { of 1960. Regulation No. } 5 \text { of } 1999 \text { Guideline to Solving the Problem of Communal } \\
\text { Land Rights of Customary Communities }\end{array}$ \\
\hline India & Recognition of Forest Rights Act, 2006 \\
\hline Iraq & The Agrarian Reform Law No. 1178 of 1970 \\
\hline Ireland & Land and Conveyancing Law Reform Act, No. 27 of 2009 \\
\hline Italy & Provincial Act of Trentino-Alto Adige, on Land Matters, 2007 \\
\hline Kenya & Community Land Act, 2016 \\
\hline Kyrgyzstan & Law on Pastures No 30 of 2009 \\
\hline Laos & Land Decree 88 of 2008 On Implementation of 2003 Land Law \\
\hline Lesotho & Land Act, 2010 \\
\hline Liberia & $\begin{array}{l}\text { Community Rights Law with respect to Forest Lands, 2009. Land Rights Law, } 2016 \text { (passed by the Lower } \\
\text { House, yet to pass Senate) }\end{array}$ \\
\hline Malaysia & Sabah Land Ordinance, Cap 68 and Subsidiary Legislation, No. 6 of 1967 \\
\hline Malawi & Customary Land Act, 2016 \\
\hline Mali & Agricultural Land Law No. 001 of 11 April 2017 \\
\hline Mauritania & Pastoral Code, 2000 \\
\hline Mexico & Agrarian Law (1934) with amendments \\
\hline Mongolia & Law on Allocation of Land to Mongolians for Ownership, 2002 \\
\hline Morocco & Decree on Collective or Tribal Lands, 1919. Decree on Delimitation of Collective Lands, 1924 \\
\hline Mozambique & Land Law, No. 19 of 1997 \\
\hline Namibia & Communal Land Reform Act, No. 5 of 2002 \\
\hline New Zealand & Maori Land Act, 1993 \\
\hline
\end{tabular}


Table 5. Cont.

\begin{tabular}{|c|c|}
\hline Country & Law and Date of Enactment \\
\hline Nicaragua & $\begin{array}{l}\text { Law of Communal Property Regime of the Indigenous Peoples and Ethnic Communities of the Autonomous } \\
\text { Regions of the Atlantic Coast of Nicaragua and of the Rivers Bocay, Coco, Indio and Maiz, } 2003\end{array}$ \\
\hline Norway & Act Relating to Bygd Commons, 1992 \\
\hline Panama & Act No. 72 of 2008 On Indigenous Lands \\
\hline P N. Guinea & Papua New Guinea Land Act, 1996 \\
\hline Paraguay & Constitution, 1992 \\
\hline Peru & $\begin{array}{l}\text { Law Decree No. } 22175 \text { (1978) and Law No. } 24656 \text { (1987), respectively on recognition of customary rights of } \\
\text { native and peasant communities }\end{array}$ \\
\hline Philippines & Indigenous Peoples Rights Act, RA 8371, 1997 \\
\hline Portugal & Law on Uncultivated Lands (Baldios), No. 68 of 1993 \\
\hline $\begin{array}{l}\text { Republic of } \\
\text { Congo }\end{array}$ & $\begin{array}{l}\text { Law No. 10-2004 Fixing Principles of General Application to National Lands and Tenure. Law No 5-2011 } \\
\text { Concerning Promotion and Protection of the Rights of Indigenous Peoples }\end{array}$ \\
\hline Romania & Restitution Law, No. 1 of 2000. Forest Code, 2008 \\
\hline Russia & $\begin{array}{l}\text { No. 49-FZ, 2001, Federal Law On Territories of Traditional Land Use of the Indigenous Small-Numbered } \\
\text { Peoples of the North, Siberia and The Far East of the Russian Federation. }\end{array}$ \\
\hline Sierra Leone & Provinces Land Act, Cap 122 (1927) \\
\hline South Africa & Extension of Security of Tenure Act, No. 62 of 1997 \\
\hline South Sudan & Land Act, 2009 \\
\hline Spain & Law on Forests, No. 43 of 2003 \\
\hline Swaziland & Constitution, 2005 \\
\hline Sweden & Act Relating to Collectively Owned Forest Lands, SFS 1952 \\
\hline Tanzania & Village Land Act, 1999 \\
\hline Timor-Leste & Special Regime for the Ownership of Immoveable Property, No. 36/III, 2017 \\
\hline Tunisia & Law on Collective Properties, 2016 \\
\hline Uganda & Land Act, 1998 \\
\hline Ukraine & Land Code, No. 2768-III of 2001 \\
\hline USA & U.S. Code (undated) Title 25 Chapter $37 \S 3501$ \\
\hline Vanuatu & Custom Land Management Act, No. 33 of 2013 \\
\hline Venezuela & Constitution, 1999. Law on Peasants and Indigenous Communities, 2005 \\
\hline Vietnam & Law on Land, 2013 \\
\hline Zambia & Land Act No. 29 of 1995 \\
\hline Zimbabwe & Communal Land Act, No. 20 of 1982 \\
\hline
\end{tabular}

Constitutions, as observed earlier, have been influential in establishing rights. Examples from different regions include Articles 9 and 10 from China's 1982 Constitution, which distinguishes between the property of the national state and the property of rural and suburban collectives; Articles 231-232 of Brazil's 1988 Constitution, which assures indigenous Indian communities permanent possession of traditional lands, and their right to defend their interests; Article 237 of Uganda's Constitution of 1995, establishing customary tenure as a lawful property regime alongside freehold, leasehold, and mailo tenure (a hybrid statutory-customary form); and articles 180 to 184 of Armenia's post-liberation Constitution of 1995, establishing communities as legal entities and lawful owners of property.

Devolutionary forest tenure from state to communities has also contributed to or responded to reforms, forested lands being a prominent communal asset in many regions [30]. The formalization of community rights to traditional rangelands is more recent [31].

Perhaps more indicative of continuing new recognition of community property is that nearly one quarter of key laws (17 of 73) have been enacted in the last decade. Draft laws also exist quite widely, such as in Nepal, India, Myanmar, and Indonesia, and more concretely, in Ghana, South Africa, Liberia, and the Central African Republic. In addition, commissions of inquiry are sitting in 13 other 
African states in 2018, charged with drafting new land policies and laws, all of which must address the status of customarily held but untitled lands (Tanzania, Zambia, Madagascar, Cameroon, Zimbabwe, Namibia, Senegal, Ivory Coast, Nigeria, Sierra Leone, Niger, Burundi, Comoros). New laws are also under consideration in an unknown number of Latin American economies.

Nevertheless, a comprehensively positive future for legally entrenched community property is not necessarily assured. Supportive laws are taking much longer to be enacted today than in the 1990s. Failure to enact implementing regulations is also familiar. From Brazil to Cambodia to Tanzania, administrations regularly seek to backtrack on key provisions, as the implications of loss of state control over large areas are recognized, and as neoliberalism reasserts the notion that the only path to economic growth remains privatization of property in the hands of individuals and under freehold and like constructs widespread in the industrial world [32]. Globalized investor demands for lands help drive this, with still limited legal provisions for communities to lease directly to investors. The result can be contradictory policies, coercing subdivision of already-titled lands [33], permitting major encroachments on community lands by expanding definitions of public property [34], and even attempts to do away entirely with recently enacted protection of community property [35].

Still, communities themselves appear more vigilant and resistant to involuntary dispossession or forced privatization, including petitioning the courts [36,37]. International support for secure community tenure is also growing, most recently illustrated in a founding principle of environmental rights articulated by the United Nations obliging member states to recognize and protect the lands, territories and resources of communities [38].

\subsection{Legal Provision for Collective Property is Expanding Its Focus}

\subsubsection{A potential Expansion to Urban Communities}

At this point, most laws target or assume that collective landholding is only viable in rural areas several laws include suburban (e.g., China) and urban neighbourhoods (e.g., Laos) as a basis for collective property. One or two others build potential for this in provisions for regularizing informal settlements in cities (e.g., Tanzania, Namibia).

Looking ahead, the rural focus could well widen to urban areas. City 'slum' dwellers are estimated to number 3 billion people by 2050 [39], most of who possess only a few square meters of space, hardly viable for individual registration at formalization. Slum neighborhoods are often ethnically definable, and rules of occupation and transfer are regularly borrowed from home villages [40]. Urban planners are showing more interest in adopting collective entitlement in these circumstances [41]. Urban Community Land Trusts are also appearing, such as in the innovative Cano Martin Pena Community Land Trust in San Juan in Puerto Rico [42].

\subsubsection{The Legal Focus on Indigenous Peoples Is Widening to Include All Rural Communities}

Especially in the Americas, the first legal changes to the status of community land rights only affected communities who define themselves as Indigenous Peoples. This has altered, as peasant farming and former slave communities are also guaranteed rights in some of these states. For example, Bolivia's land law (No. 3545 of 2006) defines communal landowners as Original, Intercultural, or Peasant Communities. Norway enacted a law relating to traditional commons attached to private farm homesteads in 1992, and a law on communal lands as held by Sami in Finnmark Province in 2005. As shown in Table 6, most land laws in force today do not distinguish categories of rural communities. 
Table 6. Indigenous Peoples and other communities as targets in 73 tenure laws.

\begin{tabular}{|c|c|c|c|c|}
\hline \multicolumn{3}{|c|}{$\begin{array}{c}\text { 1. Countries Which Provide Legally for Collective } \\
\text { Tenure without Specifying Type of Community to } \\
\text { Which This Applies }\end{array}$} & $\begin{array}{c}\text { 2. Countries Which Provide } \\
\text { Distinctly for Indigenous } \\
\text { Peoples and Other } \\
\text { Communities in Recognizing } \\
\text { Collective Tenure }\end{array}$ & $\begin{array}{c}\text { 3. Countries Which Have } \\
\text { Enacted Laws on Collective } \\
\text { Property That Are Only } \\
\text { Applicable to Indigenous } \\
\text { Peoples } \\
\text { Argentina }\end{array}$ \\
\hline $\begin{array}{c}\text { Afghanistan } \\
\text { Algeria } \\
\text { Angola } \\
\text { Armenia } \\
\text { Austria } \\
\text { Bolivia } \\
\text { Burkina Faso } \\
\text { Ivory Coast } \\
\text { China } \\
\text { Cuba } \\
\text { Ethiopia } \\
\text { Fiji } \\
\text { Germany } \\
\text { Ghana } \\
\text { Indonesia } \\
\text { Iraq }\end{array}$ & $\begin{array}{c}\text { Ireland } \\
\text { Italy } \\
\text { Kenya } \\
\text { Kyrgyzstan } \\
\text { Laos } \\
\text { Lesotho } \\
\text { Liberia } \\
\text { Malawi } \\
\text { Mali } \\
\text { Mongolia } \\
\text { Morocco } \\
\text { Mozambique } \\
\text { Namibia } \\
\text { Romania } \\
\text { Portugal } \\
\text { Papua New Guinea } \\
47 \text { (64 percent) }\end{array}$ & $\begin{array}{c}\text { Sierra Leone } \\
\text { South Sudan } \\
\text { Spain } \\
\text { Swaziland } \\
\text { Sweden } \\
\text { Tajikistan } \\
\text { Tanzania } \\
\text { Timor Leste } \\
\text { Tunisia } \\
\text { Uganda } \\
\text { Ukraine } \\
\text { Vanuatu } \\
\text { Vietnam } \\
\text { Zambia } \\
\text { Zimbabwe }\end{array}$ & $\begin{array}{c}\text { Brazil } \\
\text { Cambodia } \\
\text { Chile } \\
\text { Colombia } \\
\text { Ecuador } \\
\text { Guyana } \\
\text { Mexico } \\
\text { Nicaragua } \\
\text { Norway } \\
\text { Peru } \\
\text { Rep of Congo } \\
\text { South Africa } \\
\text { India }\end{array}$ & $\begin{array}{c}\text { Argentina } \\
\text { Australia } \\
\text { Canada } \\
\text { Costa Rica } \\
\text { Dominica } \\
\text { Venezuela } \\
\text { Panama } \\
\text { Paraguay } \\
\text { Philippines } \\
\text { Malaysia } \\
\text { New Zealand } \\
\text { Russia } \\
\text { USA }\end{array}$ \\
\hline
\end{tabular}

\subsubsection{Focusing on the Land Rights of Forest and Pastoral Communities}

Some relevant laws focus only on forests and rangelands. Examples include India's Traditional Forest Dwellers (Recognition of Forest Rights) Act, 2006, the Forest Rights Act of Guyana, 2009, the Pasture Codes of Kyrgyzstan (2009), Afghanistan (2000), Mauritania (2000), and Mongolia (2002). These are notable for state retention of resource ownership, only availing communities possessory rights, although usually in perpetuity. The laws of Angola, Peru, and Armenia are also notable for their retention of state ownership of forests in recognition of community domains.

This contrasts with most cases in this sample, where forests are ownable by communities. For example, while a State Forestry Commission in Ghana manages logging, customary communities own the forest, and accordingly, receive a share of revenue as prescribed by the Constitution at Article 267. In China's Property Law, while certain forests are owned by the national state, local forests belong to the collectives within whose lands these are located, along with mountains, grasslands, wastelands, and tidal flats (2007, Article 58). Laos's Land Law specifies that the collective owns all natural resources in its domain (2003, Article 3). Mali's Agricultural Land Law describes community lands as comprising 'vital space', including pastures and woodlands, as well as lands needed for village farm expansion (2017, Articles 11-12).

Water is much less commonly specified as the property of a community While lands once deemed public or unowned lands are quite rapidly being acknowledged as community property, water, like surface minerals and sub-surface assets, have seen a converse consolidation as state property [43]. Exceptions in this sample for water include Nicaragua's land law, which defines community property as 'constituted by the lands, waters, forests, and other natural resources contained therein which have traditionally belonged the community' (Article 2 of Law 455); Romania's Water Law, 1996, recognizing collectives as owners of lakes and rivers on their lands that are less than $5 \mathrm{~km}$ long (Water Law, 1996); and South Sudan's Land Act, which provides that 'pools, streams, swamps, and secondary rivers belong to communities on the basis of traditional ownership' (2009, section 10).

\subsection{Customary Land Tenure Is the Main Basis Upon Which Collective Property Is Legally Recognized}

This is so in 59 of the 73 country laws (81 percent) identified as providing positively for collective land ownership. This is expected; customary tenure is, by definition, a community-based property regime, and globally widespread. It also follows that statutes generally admit customary law as the 
main source of rules and norms by which communities govern their properties, subject to limitations established in constitutional and other statutes, including the land law itself.

A customary basis is more predictably rarely the case where community lands are created in modern cooperatives or unions. Nevertheless, custom is often referenced. 'Communities are allocated land or recognized land use rights by the State to preserve national identities associated with the traditions and customs of the people', says Article 131 (3) of Vietnam's Law on Land, 2013.

The 14 land laws where there is limited or no reference to customary norms include seven European countries, where collective tenure is nonetheless known to descend from customary practices (Germany, Portugal, Spain, Sweden, Romania, Ukraine and Norway). Provisions for modern collective property in Tunisia and Algeria have similar origins in their focus upon agro-pastoralists. Only Armenia, China and Cuba among the 73 states make no mention of traditional land practices in their provision for community domains.

\subsection{Provision for Private Parcels within Community Domains Is an Important Part of Laws}

This is not a contradiction in terms; community-based regimes typically provide for member families to have exclusive usufruct to homesteads within the community land area-a provision, it will be recalled from the citation by Earle, that was observable several millennia past. Today, in modern customary practice and statute, there are two main arrangements whereby the collective domain is defined, and two less common arrangements.

1. The first is where only forests, rangelands, or comparable communal areas are defined as collective property. In this sample, this is the case for Spain, Portugal, Ireland, Sweden, Norway, Austria, Germany, Romania, Ukraine, Afghanistan, Kyrgyzstan, Mongolia, and Mauritania. These assets are traditionally attached to the farms of members held distinctly under freehold or similar tenure. Many such commons are directly adjacent to settlements, others may be remote (e.g., few community properties in New Zealand are occupied).

2. The second arrangement is more usual in Asia, Africa, and Latin America, whereby community land refers to the entire domain of the community, including parcels set aside for the exclusive use of a family, individual or sub-community group under usufruct rights. Where provided for, collective title covers both communally owned lands and parcels allocated for exclusive private use of community members.

3. Less frequently, and generally only among hunter-gatherer and pastoral communities, no part of the domain is earmarked for private use. Many laws in Asia, Africa, and Latin America accept this.

4. Conversely, there are also communities whose lands are entirely comprised of discrete family parcels, but who use, govern, and transfer these in accordance with community sustained norms ('customary law'). This is the case in Vanuatu and Fiji (and also in the island states of Samoa, Nauru, Tuvalu and the Solomon Islands, not in this sample).

Many laws leave the definition of private rights in community lands to community decisionmaking/customary law. Other statutes specify how private rights may be formalized. East African laws provide examples.

1. Uganda's Land Act, 1998 does not provide for village or parish property, encouraging each family to secure its property under private customary or freehold title. This alienates those private parcels from the community area or its authority. In respect to shared lands by community members, the law provides for members to either continue their management using informal customary norms, or to formalize rights and rules in registered Communal Land Associations.

2. In contrast, Tanzania's Village Land Act, 1999 obliges each of the country's 12,000 village communities to identify their communal areas, and register these in the Village Land Register. No certificate may be issued to an individual or family for a private parcel within the village 
land area until members have assured themselves that these do not encroach upon those common lands.

3. South Sudan's Land Act, 2009 similarly provides for community authorities to distinguish between family and communal lands.

4. Kenya's Community Land Act, 2016 prescribes that a registered community landowner may '... allocate part of its land to a member or group of members for their exclusive use and occupation for such period as the registered community may determine', but that a separate title shall not be issued for such a parcel, and '... shall not be superior to community title in any way' (section 27). The law also spells out that a community may seek to convert part or all of its land into fully private properties rather than usufructs, providing this is agreed to by two thirds of community members (sections 21 and 24).

\subsection{Private and Community Properties Are Often Equally Protected}

Community and private tenure are both forms of holding exclusive rights to land, if respectively more geared to the social and economic values of property. Comparisons deserve attention. This section reviews how far community and private lands are accorded equal protection by the law.

Table 7 provides the results: two-thirds of laws equally protect community and private lands. This is directly stated, with examples in Box 1, or strongly implied, with examples in Box 2.

Box 3 gives examples of where this equivalency has been disputed, but subsequently established to be the case by court rulings. Indigenous peoples in particular often owe recognition of their rights to court decisions that have coerced parliamentary enactments, for example in Canada, Australia, New Zealand and South Africa, and in a number of Latin American countries [44,45].

Table 7. Comparison of legal protection of private and community property.

\begin{tabular}{|c|c|c|c|}
\hline \multicolumn{2}{|c|}{$\begin{array}{c}\text { Equivalent Legal Protection of Community and } \\
\text { Private Property; as Evidenced by Legal Statement, } \\
\text { by the Content of Provisions, or by Court Rulings } \\
\text { Interpreting the Law }\end{array}$} & \multirow{2}{*}{$\begin{array}{c}\text { Unequal Legal Protection } \\
\text { of Community and } \\
\text { Private Property }\end{array}$} & \multirow{2}{*}{$\begin{array}{c}\text { Insufficient } \\
\text { Information to Draw } \\
\text { Firm Conclusions }\end{array}$} \\
\hline Indonesia & Vietnam & & \\
\hline USA (IP) & Ukraine & Lesotho & Morocco \\
\hline Cambodia & Vanuatu & Namibia & Algeria \\
\hline Kenya & Uganda & Zambia & Tunisia \\
\hline Nicaragua & Sweden & Zimbabwe & Argentina (IP) \\
\hline South Sudan & South Africa & Swaziland & Canada (IP) \\
\hline Tanzania & Armenia & Malawi & Italy \\
\hline Timor-Leste & Brazil & Mongolia & Russia (IP) \\
\hline Ireland & China & Afghanistan & Spain \\
\hline Kyrgyzstan & Colombia & Mauritania & \\
\hline Laos & Ecuador & Sierra Leone & \\
\hline Mali & Ethiopia & Republic of Congo & \\
\hline Mozambique & Guyana & Australia (IP) & \\
\hline New Zealand (IP) & Ghana & Côte d'Ivoire & \\
\hline Fiji & Liberia & & \\
\hline Papua New Guinea & Austria & & \\
\hline Burkina Faso & Germany & & \\
\hline Dominica (IP) & Norway & & \\
\hline Bolivia & Portugal & & \\
\hline Chile & Romania & & \\
\hline Peru & Philippines (IP) & & \\
\hline Cuba & Malaysia (IP) & & \\
\hline Costa Rica (IP) & Mexico & & \\
\hline Paraguay (IP) & Panama (IP) & & \\
\hline Venezuela (IP) & Angola & & \\
\hline \multicolumn{2}{|c|}{50 (68.5 percent) } & 14 (19.2 percent) & 9 (12.3 percent) \\
\hline
\end{tabular}

Note: IP = Indigenous Peoples. 
Table 7 above also lists cases where equitable protection for community and private property is not provided. This is because the law fails to provide for communal landholding as property interests to the same extent as it protects individual holdings in the customary sector (e.g., Lesotho, Mongolia, Afghanistan), or because protection is weaker for community lands, even where the law acknowledges these as property interests. This may be because title is vested only indirectly in communities, but which is not the case for privately registered properties in the country (e.g., Namibia), or because customary ownership as compared to statutorily granted rights are unable to be registered directly (e.g., Zambia, Ghana, Ivory Coast, and Swaziland).

Compensation for Community and Private Lands at Compulsory Acquisition Is Not Fully Equitable

The positive picture above is dented by realities of how far communities are compensated for loss of their lands when Governments appropriate these for public purposes. This research did not examine this aspect in the laws. However, another study by the author, although focused only on Africa, found that only 12 out of 54 African Constitutions (22 percent) stipulate that compensation must be paid for all forms of interests lost at compulsory acquisition, including to occupants in good faith who do not hold evidential deeds of their rights [46]. A study by Tagliarino of 30 Asian and African land laws found that only seven of these ( 23 percent) grant compensation to landholders whether or not their lands are formally registered [47]. Furthermore, that study found that only 15 of 30 laws oblige governments to pay for takings of forests, rangelands, or other undeveloped lands belonging to communities.

Instances do exist where community lands have stronger protection than granted private lands. Customary rights are presumed, or specified in laws, as held in perpetuity, where this is not the case for statutorily granted rights in some countries, held for limited but renewable terms. Six countries in this sample have adopted the principle of Free, Prior, and Informed Consent (FPIC) prior to interference in community lands: Panama, The Philippines, and Venezuela in respect of Indigenous Peoples, and South Africa, Peru, and Colombia in respect of all communities.

Box 1. Examples of Laws Declaring Equal Protection for Community and Private Property. (Cited provisions in italics).

CAMBODIA, LAND LAW, 2001, Article 26 provides that legal title to a community includes all the rights and protections of ownership as are enjoyed by private owners.

KENYA, CONSTITUTION, 2010, Article 61: All land in Kenya belongs to the people of Kenya collectively as a nation, as communities and as individuals. Land in Kenya is classified as public, community or private. LAND ACT, 2012, Section 5: There shall be the following forms of tenure (a) freehold; (b) leasehold; (c) such forms of partial interest as may be defined under this Act and other law, including but not limited to easements; and (d) customary land rights where consistent with the Constitution. There shall be equal recognition and enforcement of land rights arising under all tenure systems and non-discrimination in ownership of, and access to land under all tenure systems.

NICARAGUA, CONSTITUTION, 1987, Article 5: The various forms of public, private, associative, cooperative and communal property shall be guaranteed and encouraged without discrimination in order to produce wealth and shall service social needs by operating freely.

SOUTH SUDAN, LAND ACT, 2009, Section 8 (6): Customary rights including those held in common shall have equal force and effect in law with freehold or leasehold rights acquired through allocation, registration of transaction (s. 8 (6)).

TANZANIA, VILLAGE LAND ACT, 1999, Section 18(1): A customary right of occupancy is in every respect of equal status and effect to a granted right of occupancy ... [Note: rights of occupancy are the only forms of ownership available, customary rights confirmed or allocated by community governments (village councils), and granted rights of allocated in mainly urban areas by state authorities].

TIMOR-LESTE, LAND LAW, 2017 brings customary rights into parity with freehold rights as prior primary rights, the former having been disadvantaged by being unregistrable, now provided for by the law (Preamble). These are defined as rights of real estate, originating in the light of customary law and based on long-term possession, and having the essential characteristics of ownership/property rights (Article $2(\mathrm{~g})$ ). 
Box 2. Examples of Laws Strongly Implying Equal Protection for Community and Private Property. (Cited provisions in italics).

COLOMBIA, CONSTITUTION, 1991, establishes a right to territory in Title XI including indigenous reservations, and which may be self governing (Articles 286-287). The Constitution also establishes that property has a social function (Article 58) and that: The state will protect and promote associational and collective forms of property.

ECUADOR, CONSTITUTION, 2008, Article 321: The State recognizes and guarantees the right to property in all of its forms, whether public, private, community, State, associative, cooperative or mixed-economy, and that it must fulfill its social and environmental role.

ETHIOPIA, CONSTITUTION, 1994, Article 40 (2): 'Private property' for the purpose of this Article shall mean any tangible or intangible product which has value and is produced by the labour, creativity, enterprise or capital of an individual citizen, associations which enjoy juridical personality under the law, or in appropriate circumstances, by communities specifically empowered by law to own property in common. Amhara National Regional State Land Law, 2006, Article 10: The land in the region may be held by individuals, groups, communities, and by government.

IRELAND, LAND AND CONVEYANCING LAW REFORM, 2009, SECTION 9: Ownership of land comprises the estates and interests specified in this Part. Section 10 lists these, including at 10(4) a public or customary right as an interest. ... The latter includes commonage rights shared by known arable landowners. They take affect as equitable interests (s. 10(6)). Section 10(7): Nothing in this Act affects judicial recognition of equitable interests.

KYRGYZSTAN, CONSTITUTION, 1993, Article 4: In the Kyrgyz Republic, private, state, communal and other forms of property shall be recognized and protected.

LAOS, CONSTITUTION, 1991, Article 17: The State protects and promotes all forms of property rights: state, collective, private domestic and foreign investments in the Lao People's Democratic Republic.

MALAWI, LAND ACT, 2016, Section 7 (3): Private land shall be classified as freehold, leasehold or customary estates.

MOZAMBIQUE, CONSTITUTION, 2004, Article 99: The national economy shall guarantee the coexistence of three sectors of ownership of the means of production: public, private and cooperative. The cooperative and social sector comprises, specifically, a. community means of production, held and managed by local communities, and $b$. means of production exploited by workers.

NEW ZEALAND, TE TURE WHENUA MAORI ACT, 1993: Land falls into three classes of Crown, General and Maori Land, the last being the subject of this Act. Part 6 on Status of Maori Land defines Maori land as including Maori customary, Maori freehold, General Land owned by Maori, and Crown Land reserved for Maori.

SOUTH AFRICA, CONSTITUTION, 1996, Article 25 (7): A person or community dispossessed of property after 19 June 1013 as a result of past racially discriminatory laws or practices is entitled, to the extent provided by an Act of Parliament, either to restitution or that property or to equitable redress.

SWEDEN, REAL PROPERTY FORMATION ACT, 1970, Section 3: According to this law, a joint property unit is land belonging in common to several property units.

VANUATU, The Custom Land Management Act, 2013, Article 2: custom owners means any lineage, family, clan, tribe or other group who are regarded by the rules of custom, following the custom of the area in which the land is situated, as the perpetual owners of that land and, in those custom areas where an individual person is regarded by custom as able to own custom land.

UKRAINE, LAND CODE, 2001, Article 83, where land ownership rights of territorial communities are specified as lands owned by village, settlement, and city territorial communities in communal ownership.

\subsection{Absolute Ownership by Communities Is Legally Denied in a Minority of Cases}

A structural difference between community and private property exists in some countries. This is where title to community property is not vested directly in communities, but in the State on their behalf, but in conditions where this is not the case for registered private owners. This can result in an unequal playing field for community and private landholders, as the State has the potential to use its trusteeship to make decisions not in the interests of community landholders.

To identify countries where this potential exists, it is necessary to exclude those where all land is vested in the nation or the State/Head of State. In these countries, property rights for all landholders are not ownership of the land itself, but ownership of rights to the nation's land. This is the situation in 22 of the 73 countries in the sample (30 percent): Angola, Algeria, Burkina Faso, Cambodia, China, Cuba, 
Ethiopia, Indonesia, Kyrgyzstan, Laos, Malawi, Malaysia, Mali, Mexico, Mongolia, Tanzania, Tunisia, Vietnam, Zambia, Australia, New Zealand, and Canada. This separation of ownership of the land and ownership of rights to the land descends from either English common law as developed in feudal times, or from policies of nationalization. For purposes here, the fact that all landholders including private persons are equally affected, provides a level playing field, at least in theory. In practice, many citizens feel the effects as more landlordism and opportunities for Governments to use their trusteeship to override local interests with more will.

Box 3. Examples Where Equal Protection of Community and Private Property Has Been Ordered by the Courts (Cited provisions in italics).

USA: In United States v. Shosone Tribes 304 U.S. 111 (1937), the Court held that the right of occupancy is as sacred as the fee-the right of perpetual and exclusive occupation of the land is no less valuable that full title in fee.

INDONESIA: The Basic Agrarian Law, 1960, protects customary land tenure (hak ulayat) (Articles 1-2) including the right of customary land communities to regulate their lands (Article 2 (4)). However, Article 3 states that communal property must be adapted to national interests. Communities have used Article 6 that 'All rights on land have a social function' to demand that community forestlands be recognized as the lawful property of communities. This was ruled to be so by the Constitutional Court in 2013. Eighteen communities have since received documents certifying this, but legal provision for collective title is yet to promulgated.

MALAYSIA: The Federal Court and High Court of Malaysia recognize that indigenous communities have a proprietary interest in their ancestral lands (High Court Rulings in Adong bin Kuqua \& Others v Kerajaan Negeri Johor \& Anor (1997). Sagong Bin Tasi v Government of Malaysia (2002) ruled that the Orang Asili Aboriginal peoples have proprietary interest in and to their customary and ancestral lands).

This may be presumed to be more so the case where only community lands are vested in the State, while private tenure is not subject to state overlordship. In this sample of 73 states, this affects the native Indian lands of Brazil, the communal lands of Zimbabwe and Namibia, the tribal territories of Morocco, the customary lands of Swaziland, the lands of 'small Indigenous Peoples' in the Russian Federation, the aboriginal land rights granted to Liberians in the 1940s, the communal (grazing) lands traditionally belonging to communities in Afghanistan, Kyrgyzstan and Mongolia, and many if not all of the native territories of Canada, Australia and USA. In some cases, including South Africa and Kenya, vesting title in the State or in government agencies of state is temporary, until communities secure case-by-case collective entitlements as prescribed by the law.

Retaining title to only community lands in the above countries stems largely from protective paternalism, intended to limit sales in ways that may be later regretted. The law in USA defines Indian lands as 'lands the title to which is held by the United States in trust for an Indian tribe or lands the title to which is held by an Indian subject to a restriction by the United States against alienation' (Section $81,3501)$. The fact that community lands, especially of Indigenous Peoples, are customarily held to be the property of generations past, present, and future, reinforces the adopted duty of protection. Yet, it may be argued that communities should be as free as individual owners to sell their lands and the lands of their descendants if they so wish, although with constraints in modern times to ensure majority consent.

\subsection{Freedom to Sell Community Property Is Freely Permitted in Only One Third of Sample Countries}

Ultimately, the distinguishing feature of private property is that it may be alienated, that is, sold freely. This is conventionally understood to not be the case for community property. Many customary norms prevent members of the community selling community property, although each member may hold an exclusive right to land, including the right to bequeath it to heirs. In some customary regimes, sale of family parcels within the domain has long been permitted, subject to permission of the traditional authority. One may refer to Earle's work cited at the beginning of this paper, showing that such transfers or sales have likely existed for thousands of years. It may be fairly safely speculated that both community and state refusal to permit sales of community lands has 
a much more recent origin, responding to unwanted losses and encroachments, or from the protective policies of modern governments.

Table 8 provides information on 60 of the 73 countries which recognized community lands as property. Thirty-four (57 percent) permit community owners to alienate certain parts of the shared property. Nineteen of these country laws permit the entire property to be sold. This requires majority community support, and/or the permission of elected or traditional leaders, and frequently, the endorsement of government authorities.

Table 8. The Legal Right of Communities to Sell their Property in a Sample of 60 states.

\begin{tabular}{cccc}
\hline $\begin{array}{c}\text { The Law Permits } \\
\text { Property }\end{array}$ & $\begin{array}{c}\text { The Law Permits Sale of } \\
\text { Some Parts of the Property } \\
\text { (e.g., Homesteads) }\end{array}$ & $\begin{array}{c}\text { The Law Forbids Sale of } \\
\text { Any Community Property } \\
\text { but Permits Leasing }\end{array}$ & $\begin{array}{c}\text { The Law Forbids Any } \\
\text { Sale or Lease of } \\
\text { Community Property }\end{array}$ \\
\hline Algeria & Canada & Brazil & Afghanistan \\
Zambia & Burkina Faso & Fiji & Kyrgyzstan \\
Angola & Chile & Mongolia \\
China & Colombia & Lesotho & Portugal \\
Ivory Coast & Laos & Burkina Faso & Panama \\
Cuba & Ghana & Romania & Paraguay \\
Germany & Guyana & Sierra Leone & Venezuela \\
Norway & Liberia & Spain & Nicaragua \\
Ireland & Zimbabwe & Swaziland & \\
Kenya & Malawi & Timor Leste & \\
Tanzania & Mexico & Ukraine & \\
Mali & South Sudan & Vanuatu & \\
Austria & Bolivia & Vietnam & \\
Mozambique & Armenia & Dominica & \\
Namibia & Malawi & India & \\
South Africa & & Cambodia & \\
Sweden & & Morocco & \\
Tunisia & & Peru & \\
Uganda & & (13 percent) \\
19 (32 percent) & 15 (25 percent) & (30 percent) & \\
\hline & & &
\end{tabular}

Of course, communities may themselves determine that their lands are not alienable or even leasable. A 1992 law in Mexico permitting peasant communities to sell parts of their lands resulted in less than one tenth taking up this opportunity by 2014 [48].

The mechanisms used to limit sales of community lands include vesting the title in the State, in trust for communities, as described above. This does not always prevent a community from lawfully leasing its land. Sale is also impossible where laws declare community property to be unsaleable. This mainly affects Indigenous Peoples. In Panama, the lands of indigenous communities are 'collective, indefinite, non-transferable, irrevocable and inalienable' (Article 9 of Act 72 of 2008). Chile's Ley Indigena 1979 recognizes Indigenous Peoples as the lawful owners of their land, but which may not be 'sold, seized, taxed or acquired by prescription' (Article 13). Nicaragua's Law 445 recognizes ownership of indigenous and ethnic communities over lands they traditionally occupy, but also guarantees their inalienability, imprescriptibility, and unattachability (Article 24). In Spain, the Forest in Common Hand Act, 1980, provides for communities to own forested lands with the equivalent effect as of private property, but which lands are also described as 'inalienable, exempt from prescription and seizure, and indivisible' (Article 132).

Other limitations may be imposed. In Cuba, the State has preferential rights to purchase cooperative lands. In Chile, authorization from the Land Office is required to sell certain categories of community property. In Peru, rights to lease community properties exist for only some classes of communities. In Morocco, community land may only be leased to members of the tribe. In Malawi, it is only the usufruct in perpetuity that may be sold, and this may occur only five years after the individual, family, or group has obtained a registered certificate of customary estate. 


\subsection{Most Nations Require Formal Entitlement to Secure Community Property}

It has been expedient for some countries to declare community lands to be property, rather than to provide for this through systematic entitlement. This is normally where most of the country area is untitled, customary property. For example, community lands cover more than 80 percent of Fiji, Ghana, Morocco, South Sudan, Papua New Guinea, Sierra Leone and Vanuatu. Declamation of these lands as "lawfully owned" changes their status overnight.

This has mainly been achieved through constitutional statement. This relieves Government of burdensome systematic titling, and takes into account the reality that titling can take many years. While positive, a more negative effect is that state funding and commitment to assisted titling is slack, and in the interim, without demarcated or mapped domains, takings or redesignation of key parts of community lands can occur more easily [49].

To recognize and uphold community ownership, most countries in this sample (39 of 71 states, 55 percent) require formal adjudication, survey, and registration, with issue of native title or other forms of entitlement (Table 9, column 3).

Table 9 also lists 18 countries where legal recognition of community property is not dependent upon statutory processes of titling (column 1). Column 2 lists another 14 countries where community lands are recognized as property with or without formal issue of titles, but where the law lays out procedures for systematic adjudication, survey, and registration of community lands, and strongly encourages uptake.

Table 9. Formalization as the Route to Recognition of Community Property in Sample of 71 Countries.

\begin{tabular}{cccc}
\hline $\begin{array}{c}\text { 1. Law Recognizes \& Protects Exclusive } \\
\text { Collective Possession without } \\
\text { Requiring Titling for This to be Upheld }\end{array}$ & $\begin{array}{c}\text { 2. As 1, But with Procedures for } \\
\text { Titling Provided and Strongly } \\
\text { Encouraged in the Law }\end{array}$ & $\begin{array}{c}\text { 3. Law Requires Formal Entitlement } \\
\text { in Order for Community Property to } \\
\text { be Legally Upheld }\end{array}$ \\
\hline Argentina & Afghanistan & Algeria & Indonesia \\
Armenia & Angola & Austria & Kyrgyzstan \\
Ecuador & Burkina Faso & Australia & Mongolia \\
Fiji & East Timor & Bolivia & Ivory Coast \\
Ghana & Kenya & Cambodia & Laos \\
Italy & Malawi & Brazil & Malaysia \\
Ireland & Mali & Canada & Mexico \\
Morocco & Mozambique & Chile & New Zealand \\
Nicaragua & Namibia & China & Panama \\
Norway & Philippines & Colombia & Paraguay \\
South Sudan & Rep. of Congo & Costa Rica & Peru \\
Papua New Guinea & South Africa & Cuba & Portugal \\
Russia & Tanzania & Dominica & Romania \\
Sierra Leone & Uganda & Ethiopia & Sweden \\
Swaziland & & Germany & Switzerland \\
Vanuatu & & Guyana & Tunisia \\
Zambia & & India & Ukraine \\
Zimbabwe & & Iraq & USA \\
& & Spain & Venezuela \\
18 (25 percent) & & Vietnam & 19 (27 percent) \\
\hline
\end{tabular}

\subsection{It is Becoming Easier for Communities to Register Directly as Landowners}

One reason for the State retaining title of community property on behalf of communities has been the legal convention that only individuals or corporate entities are jural persons, and therefore, registrable owners. Procedures for a community to form a legal entity are often complex, expensive, and beyond community means, notably the case in both Australia and Canada for Indigenous Peoples. Less burdensome processes are provided in Cuba, Kyrgyzstan, Mexico, China, and Germany, whereby state agencies establish the entity for the community.

Along with widening access to socially collective tenure, ease of access is visibly favoured. This includes accepting a community as a legal person for purposes of property registration without its 
incorporation, or by registering itself through steps the community may take at no cost and with no need for external expertize. Sixteen of 22 new land laws (73 percent) since 2000 provide for this. Examples are given in Box 4.

Box 4. Examples of Laws where the Community is a Legal Person for Purposes of Registering Land Ownership.

ANGOLA: the community may seek title without incorporation for a Community Useful Domain through straightforward procedures laid out in the Land Law, 2004 and in Regulations 2007.

BOLIVIA: the Constitution 2009 recognizes rural communities as human collectives, to self-determine their territoriality and own land and territory collectively (Article 30).

BURKINA FASO: a community is recognized as customarily a collective landowner and unregistered rights held to be property assets, acquired through assignment, certificate of evidence or acquisition by ordinary processes including inheritance, purchase, donation and legacies (Law 034 of 2012 On Agrarian Reform).

CAMBODIA: a named and described indigenous community may receive an entitlement (Land Law, 2001, Articles 8 \& 10).

AFGHANISTAN: customary, shariat, and statutory allocation letters are accepted as evidence of possession of a described pasture to a named community and which land may also be more formally registered as under its exclusive use (Land Management Law, 2017, Law on Pasture and Grazing Land, 2000, Articles 2 \& 4).

ECUADOR: the Constitution establishes that communities who hold collective land ownership are recognized as an ancestral form of territorial organization, and are acknowledged as owners thereof (2008, Articles 57-60).

ETHIOPIA: land holding rights may be issued to an individual, a group of people or to a community (Amhara National Regional State Proclamation No. 133 of 2006 On Land).

FIJI: Clan lands are directly registered as Native Reserves (iTaukei Land Act, Cap 134).

MOZAMBIQUE: customary occupancy is lawful and protected without registration but a community may secure a standard land title also available to others through a procedure laid out in the law, registered in its own name (Land Law, 1997, with Regulations Governing Procedure, No. 66 of 1998).

TANZANIA: 'A person, a family, a group of persons recognized as such under customary law or who have formed themselves together as an association, a primary cooperative society or as any other body recognized by any law which permits that body to be formed, who is or are villagers ... and all of whom are citizens, may apply to the village council of that village for a customary right of occupancy' (Village Land Act, 1999, Section 22 (1)).

KENYA: 'A community must first register itself with the county government, providing a list of members, and which list shall be updated annually, the rules and regulations by which the community has agreed to manage its property, and the list of persons it has appointed or elected in a public meeting to serve as the community land management committee, along with minutes of that meeting' (Community Land Act, 2016, Section 7 (6)). Once registered, the community may then apply to have its lands adjudicated, surveyed and registered (Sections 7 and 10).

\subsection{Communities May Govern Their Properties to the Same Degree as Private Persons}

Few question the authority of a private landowner or corporation to make decisions about the property within the limits of planning or other regulations. Authority is more complex for multi-person owners. Nonetheless, a review of relevant legal provisions in a sample of 44 countries finds that all but three identify the community as the primary decision-maker ( 93 percent). The exceptions are Zimbabwe, Uganda, and Ukraine, where primary authority is vested in local governments.

In 25 countries, community governance is supervised by local governments, land boards, commissions, or by paramount chiefs and councils. Some of these bodies have powers to approve or deny decisions made by the community or its land council. Land transfers from community lands require the approval of such state agencies in Cuba, Chile, and Portugal. In Laos, Vietnam and China, community properties are at one end of a linked continuum of properties to the national State, with each level exercising a source of influence, appeal, and advice to the level below it.

While these findings suggest less independent authority over community property than is the case for private owners, community-level jurisdiction indisputably anchors the community property 
system. Community level institutions are endorsed or created by the law in 26 of 44 countries (59 percent). These include boards of directors of agricultural communities (Chile), Community Land Management Committees (Kenya), Village Land Commissions (Mali), Commons Boards (Norway), Boards of Indigenous Land Groups (Papua New Guinea), Peoples Councils (Vietnam), and Pasture Unions (Kyrgyzstan).

The accountability of these bodies to community landowners is usually specified. The latter constitute assemblies in a number of countries. These elect officers to perform day-to-day land management (e.g., Romania, Kenya). In Vanuatu, the assembly (nakamal) explicitly includes children, as the future guardians of community lands held in perpetuity. Inclusive decision-making is specified in 24 of 44 relevant laws (54 percent). Seven of the ten newest laws (2013-2017) emphasize democratic norms, with quorums stipulated in the laws to ensure maximum participation of community members (Mali, Afghanistan, Timor Leste, Kenya, Malawi Vietnam and Vanuatu).

\subsubsection{Customary Rules Play a Major Role in Collective Property Management}

In 33 of 44 laws (75 percent), the community may adopt customary norms and/or develop community- based rules through which the property is governed. A hybrid approach is widely indicated, the law admitting customary norms but also requiring adherence to constitutional rights and laws, and the creation of community based organs to ensure maximum participation. Portugal's law relating to communal rangelands and forests ('wastelands') reads:

'The wastelands are administered in their own right, by their co-owners in accordance with applicable customs and habits or, in their absence, through democratically elected bodies or organs. Local communities are organized, for the exercise of representation, actions, management and supervision through an assembly of co-owners, a governing board and a supervisory board. The members of the board of the assembly and the governing board and the supervisory board are elected for periods of two years, renewable, and remain in office until they are replaced'. (Law on Uncultivated Lands (Baldios), No 68 of 1993, Article 11)

\subsubsection{Links between Community Land Governance and Local Government}

In a number of cases, community property is defined through a corollary system wherein communities constitute the most local level of government. Armenia's Land Code of 2001 is a good example. The community owns land and other property within the prescribed area, with the exception of lands owned by the state (forests), and parcels within the domain owned by natural and legal persons. The community body is a legal person under public law. The community elects a Head of Community and a Council of Elders, for terms of five years to serve as the local self-government body, including decision-making on all land and resource matters. Residents participate in decision-making through local referenda. Powers of State bodies may be delegated to local self-government bodies (Articles 179-184).

\section{Conclusions}

The results of this study are surprising, even to this author, a specialist in the subject. Determining if a country's laws meet criteria to be deemed positive for community property was especially difficult in some cases and four may have been too harshly and four too generously assessed. Overall, the picture remains stable: most modern states (around three-quarters) provide for community lands as a lawful class of property. Moreover, while distinct from classically individualized and state-granted private property, this form of land ownership largely enjoys equivalent legal protection.

There are also signs of continuing new and planned provision for this in more countries, suggesting an expanding trend. Moreover, this is apparent in all regions of the world (perhaps excepting the Middle East), confined neither to capitalist nor to socialist economies. While the focus thus far has been firmly upon rural lands, the utility of collective property in the poorest parts of 
expanding cities has been observed. Overall, it may be concluded that socially-based collective property is fast becoming an accepted part of property relations guided and protected by statutes, taking its place among more traditional and individual-centric norms. The construct is itself being modernized, seemingly accepted by parliaments, of only grudgingly, as having roles to perform which individualized, absolute property rights have been unable to cater to, with rising risks of insecurity of habitation and livelihood for millions of citizens. Supporting factors include:

(a) the inherently devolved nature of community-based tenure as governed at the most local level of rural society, pertinent to discernible demand for more devolved and inclusive governance in many regions;

(b) the ability of this system to encompass naturally collective off-farm resources of critical use to community members-assets that have been long excluded in many countries as owned or generically ownable other than by the State; and

(c) as being so proximate to land users and their socio-economic and cultural realities, possessing unique relevance to local conditions and easy adaptability in rules and practices to changing demands.

In the process, customary tenure, so widely practised in many regions, is, in effect, becoming indistinguishable from introduced forms of autonomous collective landholding. This can be seen in:

(a) shifting gender property relations at community level;

(b) adoption of family tenure into many norms;

(c) more precise distinction between family and common property within the community domain;

(d) rising flexibility in to whom and how lands may be transferred; and

(e) most remarked upon in this study, changes expressing pressing demands for fuller popular inclusion in decision-making on land matters.

This adaptability also reflects modern reality that even the remotest community of persons is both defined and bound by socio-spatial interests in the local environment, and citizens of modern states whose constitutions dictate human rights and governance agendas with ever-more precision, and to which communities increasingly contribute.

Changes also respond to several decades of globalizing human rights awareness and among which tenure security is slowly finding its place as a human right in relevant circumstances. Globalized connectivity among countries and their populations meaning there is more popular knowledge as to changes in other countries also plays a role. There has also been perhaps some political embarrassment in post-colonial states that so many millions of citizens have had to wait one to four centuries for laws to acknowledge that their lands were already owned, and continue to be owned, if not in ways that European norms cared to embrace. Self-definition by Indigenous Peoples of themselves and their lands, is also contributing to changed status of community-based tenure, with laws seen in this study to have expanded to all landed communities.

In a legal sense, there are also signs of weakening boundaries between customary and statutory law, delivering as much integration as pluralism in legal support. It may be safely speculated that customary landholders themselves are more rather than less demanding that national statutes embeds and protects norms and rights once deemed the preserve of customary tenure.

These shifting sands over the last few decades are unsurprising, in light of rising state, private and commercial demand for lands, resources on and under lands, and social polarization in interests and demands, threatening the interests of poor populations who may have in the past not found their interests practically interfered with. It is significant, this study finds, that legal requirement that communities secure formal title to their lands is not disappearing, even as many parliaments accept that community-based property does, after all, already exist, whether or not past laws have acknowledged this. This is testimony to raised concern about mass insecurity by both state parties 
and their populations. Of course, the drivers may be different, for some a means to feed a market in land, for others to help limit encroachment or willful land takings with more evidence of ownership. Recognition of a community as a juridical person for registration purposes is one of the simplifications towards titling that this research has noted.

More subtle changes are afoot. The meaning of property in land itself is altering, widening its scope to admit different constructs and attributes, and without loss of protection because of those differences. This will open the way to more innovation during the 21st century, especially as socio-spatial collective tenure evolves further in response to urban circumstances.

The legal paradigms in this transformation are imperfect. Even laws that are most supportive of community-based tenure have shortfalls, both intended and unintended, which may easily be exploited to slow down the application of law. Resistance of traditional authorities to lessen their control over land disposition or to make decisions without popular consent, also visibly slow reforms in some countries, as does heightening polarization among national decision-makers and society as to how far all land must be a marketable commodity, a never-ending debate. Or, as has been mentioned in this study, reluctance around legal recognition of community property stems in part from the reluctance of governments to dramatically decrease the scope of public lands over which they have primary control.

In short, iteration-or reiteration-of socially collective property and its entrenchment in statutes-remains a work in progress. The fact that laws find it necessary to be explicit that community and private property have equal force and effect suggests that questions still arise as to why and how this should be so. The efforts of millions of beneficiaries, mainly poor citizens, to sustain progress, vigilance around attempts to renege on commitments, likely surges in encroachment upon rights and land, and resort to courts to secure impartial support for tenure security, will be needed for some time.

In the interim, private, public, and community lands will continue to battle for space and make claims upon each other in legal and practical terms, the latter often in state supported land takings that rank commercial land development above majority tenure security. In respects, the tensions are not much different from those that defined the philosophical debates of Plato and Aristotle, Locke and Hobbes, Mill and Marx, or Polanyi and Friedman on the role of property in the State. Perhaps the most that can be hoped for is periodic rebalancing in property relations between the social and economic, the collective and the individual, governments and their citizens, subsistence and commercial demands, and that justice as popularly perceived at the time, is achieved more often than not.

Funding: No grant has been received in support of this research.

Conflicts of Interest: The author declares no conflict of interest.

\section{References}

1. $\quad$ Earle, T. Property in prehistory. In Comparative Property Law Global Perspectives; Graziadei, M., Smith, L., Eds.; Edward Elgar: Cheltenham, UK; Northampton, MA, USA, 2017.

2. Bell, A. A Theory of Property; Cambridge University Press: Cambridge, UK, 2005.

3. Neale, R.; Kamenka, E. Feudalism, Capitalism and Beyond; Australia National University Press: Canberra, Australia, 1975.

4. Hobsbawn, E. The Age of Capital 1848-1875; ABACUS: Meilen, Switzerland, 1997.

5. Waldron, J. Property and ownership. In The Stanford Encyclopedia of Philosophy, Winter 2016 Edition; Zalta, E., Ed.; Stanford University: Stanford, CA, USA, 2016; Available online: https:/ / plato.stanford.edu/archives / win2016/entries/property/ (accessed on 1 April 2018).

6. Lipton, M. Land Reform in Developing Countries: Property Rights and Property Wrongs; Routledge: London, UK, 2009.

7. Alden Wily, L. Customary Land Tenure in the Modern World; Rights and Resources Initiative: Washington, DC, USA, 2012.

8. Alden Wily, L.; Devendra, C.; Sharma, S. Land Reform in Nepal. Where Is It Coming from and Where Is It Going? Kathmandu Publishers: Kathmandu, Nepal, 2009. 
9. Rosset, P.; Patel, R.; Courville, M. Promises Land: Competing Visions of Agrarian Reform; Institute for Food and Development Policy, Food First: Oakland, CA, USA, 2006.

10. Borras, S., Jr. Pro-poor Land Reform a Critique; The University of Ottawa Press: Ottawa, ON, USA, 2007.

11. Chen, F.; Davis, J. Land Reform in Rural China Since the Mid-1980s (Undated). Available online: http:/ / www.fao.org/docrep/x1372t/x1372t10.htm (accessed on 1 April 2018).

12. Food and Agricultural Organization (FAO). Land Reform and Structural Adjustment in Sub-Saharan Africa: Controversies and Guidelines; FAO Economic and Social Development Paper 107; FAO: Rome, Italy, 1992.

13. Deininger, K. Land Policies for Growth and Poverty Reduction; The World Bank and Oxford University Press: Washington, DC, USA, 2003.

14. Niezen, R. The Origins of Indigenism: Human Rights and Politics of Identity; University of California Press: Berkeley, CA, USA, 2003.

15. Ulgen, O. Developing the doctrine of aboriginal title in South Africa: Source and content. J. Afr. Law 2002. [CrossRef]

16. International Labour Organization (ILO). Indigenous and Tribal Peoples Convention; ILO: New York, NY, USA, 1989.

17. Borras, S., Jr.; Edelman, M.; Kay, C. Transnational Agrarian Movements Confronting Globalization; Blackwell Publishing Limited: Chichester, UK, 2008.

18. Moyo, S.; Yeros, P. Reclaiming the Land the Resurgence of Rural Movements in Africa, Asia and Latin America; University of Chicago Press: Chicago, IL, USA, 2005.

19. United Nations. Revised Draft United Nations Declaration on The Rights of Peasants and Other People Working in Rural Areas. Revised Draft 12 February 2018. Available online: http:/ /www.ohchr.org/EN/ HRBodies/HRC/RuralAreas/Pages/5thSession.aspx (accessed on 1 April 2018).

20. Oxfam. International land coalition, rights and resources initiative. In Common Ground. Securing Land Rights and Safeguarding the Earth; Oxfam: Oxford, UK, 2016.

21. LandMark. Global Platform on Indigenous and Community Lands. Available online: www.landmarkmap. org (accessed on 27 May 2018).

22. De Janvry, A.; Sadoulet, E. Land Reform in Latin America: Ten Lessons Towards a Contemporary Agenda. Prepared for the World Bank's Latin American Land Policy Workshop, Pachuca, Mexico, 14 June 2002. Available online: https://are.berkeley.edu/ esadoulet/papers/Land_Reform_in_LA_10_lesson.pdf (accessed on 1 April 2018).

23. USAID. Property rights and resource governance. In USAID Mexico Country Profile; USAID: Washington, DC, USA, 2011.

24. Smith, R. We are here: The state of community-based landscapes in Peru. In Landscapes of Equity: The Question for Environmental Justice in the Andes/Amazon Region; Robins, N., Fraser, B., Eds.; University of Nebraska Press: Nebraska, NE, USA, 2018. (In Press)

25. Alden Wily, L. Estimating National Percentages of Indigenous and Community Lands: Methods and Findings for Africa; LandMark: Washington, DC, USA, 2015.

26. Hunt, D. Some outstanding issues in the debate on external promotion of land privatisation. In Development Policy Review; Overseas Development Institute: London, UK, 2005.

27. Bruce, J.; Migot-Adholla, S. Searching for Land Tenure Security in Africa; Kendal/Hunt Publishing Company: Dubuque, IA, USA, 1994.

28. Jacoby, H.; Minten, B. Land Titles, Investment, and Agricultural Productivity in Madagascar: Poverty and Social Impact Analysis; The World Bank: Washington, DC, USA, 2006.

29. Ministry of Lands. Session Paper No. 3 of 2009 on National Land Policy; Ministry of Lands, Republic of Kenya: Nairobi, Kenya, 2009.

30. Rights and Resources Initiative. What Rights? A Comparative Analysis of Developing Countries' National Legislation on Community and Indigenous Peoples' Forest Tenure Rights'; Rights and Resources Initiative: Washington, DC, USA, 2012.

31. Bruce, J.; Ngaido, T.; Nielsen, R.; Jones-Casey, K. Land Administration to Nurture Development (Land) Protection of Pastoralists' Land Rights: Lessons from the International Experience; Tetra Tech: Burlington, VT, USA, 2013.

32. von Bennewitz, E. Land tenure in Latin America: From land reforms to counter-movement to neoliberalism. Acta Univ. Agric. Silvic. Mendel. Brun. 2017, 65. [CrossRef] 
33. Sulle, E. Of Local People and Investors: The Dynamics of Land Rights Configuration in Tanzania; Working Paper; Danish Institute for International Studies: Kopenhagen, Dänemark, 2017.

34. Alden Wily, L. The community land act in Kenya. Opportunities and challenges for communities. Land 2018, 7, 12. [CrossRef]

35. Darby, M. Hurricane-Hit Barbudans Protest to Save Communal Land from Developers. Climate Home News. 19 April 2018. Available online: http:/ / www.climatechangenews.com/2018/04/19/hurricane-hitbarbudans-protest-save-communal-land-developers/ (accessed on 19 April 2018).

36. Branford, S. Indigenous People Win Key Land Rights Victory in Brazil's Supreme Court. Mongabay. 18 August 2017. Available online: https:/ /intercontinentalcry.org/indigenous-peoples-win-key-land-rights-victorybrazils-supreme-court/ (accessed on 1 April 2018).

37. Minority Rights Group. Huge Victory for Kenya's Ogiek As African Court Sets Major Precedent for Indigenous Peoples' Land Rights; Minority Rights Group: London, UK, 2017.

38. Secretariat, United Nations. Report of the Special Rapporteur on the Issue of Human Rights Obligations Relating to the Enjoyment of a Safe, Clean, Health and Sustainable Environment. Presented at the Human Rights Council at Thirty-Seventh Session, 26 February-23 March 2018. Available online: https:// documents-dds-ny.un.org/doc/UNDOC/GEN/G18/017/42/PDF/G1801742.pdf?OpenElement (accessed on 1 April 2018).

39. Barbiere, C. French Urban Expert: 'In 20503 Billion People Will Live in Slums'. EuroActive France. 6 March 2017. Available online: https:/ / www.euractiv.com/section/development-policy/interview / french-urbandevelopment-expert-in-2050-3-billion-people-will-live-in-slums / (accessed on 1 April 2018).

40. Hatcher, C. Rural-urban linkages in the context of sustainable development and environmental protection. In Global Land Outlook Working Paper; UNCCD: New York, NY, USA, 2017.

41. Collier, P.; Glaeser, E.; Venables, T.; Blake, M.; Manwaring, P. Secure, legally enforceable and marketable land rights for urban development. In IGC Cities that Work Policy Brief; International Growth Centre: Oxford, UK, 2017.

42. Stanchich, M. People power in Puerto Rico: How a canal community escaped gentrification. In The Guardian; The Guardian Newspaper: London, UK, 2017; Available online: https:/ /www.theguardian.com/cities/2017/ jan/18/people-power-puerto-rico-canal-community-escaped-gentrification (accessed on 1 April 2018).

43. Alden Wily, L.; Dubertret, F.; Veit, P.; Reytar, K.; Tagliarino, N. Water rights on community lands: LandMark's findings from 100 countries. Land 2017, 6, 77. [CrossRef]

44. Burgorgue-Larsen, L.; de Torres, A. The Inter-American Court of Human Rights: Case Law and Commentary; Oxford University Press: Oxford, UK, 2011.

45. United Nations. Land and Human Rights Annotated Compilation of Case Law; Human Rights Office of the Commissioner: New York, NY, USA, 2015.

46. Alden Wily, L. Compulsory acquisition as a constitutional matter. The case in Africa. J. Afr. Law 2018, 62, 77-103. [CrossRef]

47. Tagliarino, N. The status of national legal frameworks for valuing compensation for expropriated land: An analysis of whether national laws in 50 countries/regions across Asia, Africa, and Latin America comply with international standards on compensation valuation. Land 2017, 6, 37. [CrossRef]

48. Perramond, E. The rise, fall and reconfiguration of the Mexican "Ejido". Geogr. Rev. 2008, 98, 356-371. [CrossRef]

49. Alden Wily, L. Risks to the sanctity of community lands in Kenya. A critical assessment of new legislation with reference to forestlands. Land Use Policy 2018, 75, 661-672. [CrossRef]

(c) 2018 by the author. Licensee MDPI, Basel, Switzerland. This article is an open access article distributed under the terms and conditions of the Creative Commons Attribution (CC BY) license (http://creativecommons.org/licenses/by/4.0/). 